\title{
Environmental determinants of the current and future distribution of seven Ottelia Pers. species in African freshwater bodies
}

\section{Boniface K. Ngarega}

Key Laboratory of Aquatic Botany and Watershed Ecology, Wuhan Botanical Garden, Chinese Academy of Sciences, Wuhan 430074, China

\section{John M. Nzei}

Key Laboratory of Aquatic Botany and Watershed Ecology, Wuhan Botanical Garden, Chinese Academy of Sciences, Wuhan 430074, China

\section{Josephat K. Saina ( $\nabla$ Bon@wbgcas.cn )}

Key Laboratory of Aquatic Botany and Watershed Ecology, Wuhan Botanical Garden, Chinese Academy of Sciences, Wuhan 430074, China

\section{Marwa Waseem A. Halmy}

Department of Environmental Sciences, Faculty of Science, Alexandria University, Alexandria 21511, Egypt

\section{Jin-Ming Chen}

Key Laboratory of Aquatic Botany and Watershed Ecology, Wuhan Botanical Garden, Chinese Academy of Sciences, Wuhan 430074, China

\section{Zhi-Zhong Li}

Key Laboratory of Aquatic Botany and Watershed Ecology, Wuhan Botanical Garden, Chinese Academy of Sciences, Wuhan 430074, China

\section{Research Article}

Keywords: Ottelia; Habitat suitability; Species distribution modeling; climate change; African freshwater bodies

Posted Date: June 3rd, 2021

DOI: https://doi.org/10.21203/rs.3.rs-588497/v1

License: (c) (1) This work is licensed under a Creative Commons Attribution 4.0 International License. Read Full License 


\section{Abstract}

Understanding the influence of environmental covariates on plants' distribution is critical, especially for aquatic plant species. Climate change is likely to alter the distribution of aquatic species. However, knowledge of this change on the burden of aquatic macroorganisms is often fraught with difficulty. Ottelia Pers., a model genus for studying the evolution of the aquatic family Hydrocharitaceae, is mainly distributed in slow-flowing creeks, rivers or lakes throughout the world's pantropical areas. Due to recent rapid climate changes, the natural Ottelia populations have declined significantly. In the present study, we use maximum entropy (MaxEnt) to explore the environmental drivers of seven Ottelia species distribution in African freshwater bodies. The models use known background points to determine how environmental covariates vary spatially and produce continental maps of these species' distribution. We also estimate the possible influences of the optimistic and extreme pessimistic Intergovernmental Panel on Climate Change (IPCC) pathway scenarios and identify high suitability areas under these scenarios. Model performances were statistically significant than random expectations with Area Under Curve (AUC) values above 0.831 , indicating the good performance of the models. We observe that our studied Ottelia species had distinct spatial patterns influenced by climate variations (e.g. Bio9- mean temperature of driest quarter, Bio12- annual precipitation, and Bio14- Precipitation of the driest month). While there is a lack of accord in defining the limiting factors for the distribution of the seven species, it is clear that watertemperature conditions have promising effects when kept within optimal ranges. Niche overlap analyses showed that most Ottelia species have similar but not equivalent climatic niches. In addition, considering the expected warming in the future, the persistence and survival of the Ottelia species in Africa could be compromised. The present findings provide a theoretical basis for the distribution of various Ottelia species in Africa.

\section{Introduction}

The world is evolving rapidly, affecting biodiversity in several ways (IPCC, 2014). Apart from the habitat loss known to threaten most species (Hanski et al., 2013), the increased human emissions of $\mathrm{CO}_{2}$ from burning fossil fuels and other greenhouse gasses that cause climate change (IPCC, 2014) also affect living creatures. Similarly, the loss of biodiversity has been identified as one of the most significant threats to ecosystems, endangering human well-being and ecosystem resilience (Butchart et al., 2010; Hoekstra et al., 2005).

Aquatic ecosystems are among the most diverse and sophisticated ecosystems around the world. Due to human growth and development, these habitats face a slew of challenges, including habitat loss, degradation, and fragmentation (Murphy et al., 2019). Regardless of the importance of aquatic communities and their looming challenges, assessing aquatic assemblages for conservation reasons has proven extremely difficult, particularly given limited resources (Wilson et al., 2006). The instability generated by climate change trends is among the most significant problems facing conservation policies, as any policy must forecast the circumstances that habitats will likely encounter in the future (Pressey et al., 2007). Therefore, understanding the current aquatic biodiversity status, extinction trend threats, and 
formulation of conservation strategies requires prior knowledge of the species distribution (McCarthy et al., 2008; Bailie 2004), and to deal with these uncertainties, several researchers have attempted to model the distribution of aquatic species in the future in order to offer conservation measures.

Over the past few decades, Africa has observed regional and continental climate change that has severely affected the water systems in the region (Serdeczny et al., 2017; Cavé et al., 2003). The future projections have suggested that there will be periods of shifts from decrease to increase in precipitation (Shepard, 2019; Serdeczny et al., 2017). Generally, sea levels, river flows, and direction and rainfall patterns will be majorly affected worldwide as predicted by the IPCC report (Bernstein et al., 2008), as well as the expected increased frequencies of heat waves (IPCC, 2014). Africa faces the risk of losing 17\% of the drainage due to the 10\% drop in precipitation by 2050 (Misra, 2014; Nyong and Niang-Diop, 2006). These changes foretell significant potential alterations in the ecology and distribution of wetland species, coupled with expansion and shifts of ranges where species occur (Thornton et al., 2011; De Wit and Stankiewicz, 2006). Even so, these wetland species face risks of losing their habitats, and accelerated climate change may drive them into extinction (McLaughlin et al., 2017; Corlett, 2016).

Genus Ottelia includes aquatic species possessing a wide distribution in tropical, subtropical, and temperate regions of the globe (Cook and Urmi-König, 1984; Cook et al., 1983). Cryptic speciation observed among specific species recently has heightened interest for further research on the genus (Li et al., 2020; Li et al., 2019; Ito et al., 2019). Irrespective of the high diversity of the Ottelia species (Fan et al., 2019; Guo et al., 2019; Li et al., 2019; Zhai et al., 2018), few studies have used georeferenced data and statistical models to assess the effect of climate on the expansion or reduction of the geographical distribution of Ottelia species (Guo et al., 2019). In Africa, this genus has been assessed on a molecular and taxonomical basis (Li et al., 2020; Symoens, 2009). However, no previous studies on the continent have evaluated the ENMs of the genus, and only 0 . acuminata has received attention regarding ENMs elsewhere (Guo et al., 2019). This species' future projections have shown a general stable habitat under the extreme greenhouse gas emission scenario RCP 8.5, with a slight shift of the range polewards. In addition, tropical Africa possesses a unique topography, and different ecoregions typically bear different environmental characteristics (Murphy et al., 2019). It is anticipated that every plant species in this region will show a complex feedback mechanism to climate change (Corlett, 2016). Niche separation among Ottelia populations of sympatric species favors long-term coexistence, and the resultant features or the niche disparities cause higher competition within a species' populations than that with other species populations (Li et al., 2020; Chesson, 2000). Therefore, there is the need to assess ENMs for the genus Ottelia to discourse factors that would influence the distribution, and diversification of this genus, as a case study in African freshwater environments, on a climate change basis.

Ecological niche models (ENMs) are powerful tools widely used in assessing the impacts of climate and environmental change on species, as well as their habitat suitability (Elith and Leathwick, 2009; Hirzel et al., 2006). The maximum entropy (MaxEnt) is preferred among the presence-only models since it has prior positive outcomes and has been used widely (Elith et al., 2011; Phillips et al., 2006). has been shown to outdo the genetic algorithms and the regression models in SDM (Heikkinen et al., 2006; Elith et al., 
2006) and could account for the complex interactions between geographical features responsible for the absence or presence of water basins (Phillips and Dudik, 2008). Furthermore, MaxEnt can predict species' habitat suitability in the unknown wetlands/basins using presence-only data and has been successfully

conducted in several wetland species, such as O. acuminata (Guo et al., 2019) and Hydrocotyle umbellata and Salvinia auriculata (Heneidy et al., 2019).

Our study focuses on using the ENMs to estimate the influence of environmental change on seven African Ottelia species and to detect the impact of climate change by 2050s under moderate and extreme greenhouse gas emissions using MaxEnt (Phillips et al., 2006). Additionally, we highlight the relative increases and decreases of areas of habitat suitability for studied seven Ottelia growing regions under current and future periods and further discuss the niche overlap among the species in the region and probe the reasons for the patterns. While this study focuses on Ottelia, some of its results are significant and may apply to other macrophytes at a vast scale.

\section{Materials And Methods}

\subsection{Study area and species}

Tropical Africa is characterized by abundant reservoirs that include basins such as the Lake Victoria, Congo, and Zambesi Basins, with large rivers that include Niger, Zambezi, and Congo (Lewis and Berry, 2012). The availability of these extensive water systems that are widely interconnected provides an excellent opportunity to assess their complexity due to topography (De Dominicis et al., 2015). Worthy to note is that a significant percentage of the freshwater and river basins are restricted to two or more countries. An array of climates characterizes this region, for instance, semiarid, desert, tropical monsoon equatorial climate. We divided the study area into $10 \times 10 \mathrm{Km}$ grid cells. The distribution of seven Africa Ottelia species viz. O. cylindrica (T.C.E.Fr.) Dandy, O. muricata (C.H. Wright) Dandy, O. kunenensis (Gurke) Dandy, O. fischeri (Gurke) Dandy, O. ulvifolia (Planch.) Walp, O. exserta (Ridl.) Dandy and O. verdickii Gurke were modeled and projected to evaluate future climate change impacts on water systems in tropical Africa. Lastly, modeling the distributions of O. Iuapulana, O. lisowskii Symoens, O. scraba Baker, $O$. somalensis Chiov., and $O$. alismoides (L.) Pers. which had less than few occurrences, was not possible. For accurate modeling and producing fitting models, a species requires more than three occurrence records (van Proosdij et al., 2016).

\subsection{Collection of occurrence data}

The African Ottelia species occurrence data and localities were obtained from different sources, including the Global Biodiversity Information Facility (GBIF, http://www.gbif.org/, accessed on March 2020), TROPICOS (http://www.tropicos.org/, accessed on March 2020), Zambia Flora (https://www.zambiaflora.com/, accessed on March 2020), hitherto published literature (Kennedy et al., 2015) and our fieldworks (2018-2019). Notably, there is substantial ambiguity present in the taxonomical literature of the genus Ottelia in Africa due to the tantamount use of various names to identify one species, e.g., O. ulvifolia, O. exserta, among others (Ferrer-Gallego et al., 2016). Therefore, to 
evade any misperception arising from this taxonomic uncertainty, only the literature information with listed specific epithet according to Plant List (IPNl; The Plant List, 2010) was considered, discarding all the synonyms that refer to one species. We cross-checked all herbarium specimens for probable misidentification and noted the locality information on label data. For the herbarium records that lacked geographic coordinates but had locality occurrence descriptions, we used Google Earth ${ }^{\text {TM }}$ to georeference them at three decimal degrees accuracy levels. With the data obtained, including a combined dataset 505 for all species records for the study area, a spatial rarefying of each species' localities was performed on R package "spThin" v. 0.1.0 (Aiello-Lammens et al., 2015) to reduce the autocorrelation between the points at each grid cell of ten by ten $\mathrm{km}$. Occurrence data and field survey localities are shown in Table S1, and displayed in Fig. 1.

\subsection{Environmental variables}

Climatic data variables attained from the period 1950-2000 were obtained from the WorldClim database (https://www.worldclim.org/bioclim) at a resolution of 2.5-arcmin from the equator (Hijmans et al., 2005). This dataset (19 variables) includes a summary of information on average, extremes, and seasonality patterns of precipitation and temperature. We ran a Pearson correlation test on the 19 bioclimatic factors to exclude the collinear ones since presence-only models are generally affected by collinearity between variables (Dormann et al., 2007). We used a threshold-dependent variance inflation factor (VIF) correlation at a threshold of 0.7 using the "cor" function in R 3.6.2 (R-Core-Team, 2019). Nine variables were selected following their restricted collinearity and used for preceding analyses (Table S2). Ottelia is an aquatic genus, and due to its dependency on water, we included precipitation of the driest quarter (Bio17) and annual precipitation (Bio12) as relevant to water availability for the genus. We also incorporated elevation (http://srtm.csi.cgiar.org/) as an extra variable since Ottelia is affected by geography (Symoens, 2009). It is worthy to note that altitude affects freshwater aquatic species since they are restricted to basins bearing certain features, and elevation plays a vital role in these features, for instance, available vegetation in the surrounding, nutrients, speed of flow, among others (Nori and RojasSoto, 2019). In addition, different Ottelia species have been associated with their type habitat and observed to be affected by the direction of water movement (Kennedy et al., 2015); therefore, we calculated 'slope' in ArcGIS v. 10.5 and added the raster variable. The Land use was obtained from http://www.fao.org/faostat/en/\#data/RL, population density from

http://sedac.ciesin.columbia.edu/data/collection/gpw-v4 (CIESIN, 2017), and water area from HydroSHEDS dataset (http://hydrosheds.cr.usgs.gov). Future prediction variables included the global climate models (GCM) from the Community Climate System Model (CCSM; Gent et al., 2011) at 2.5 arcmin according to McSweeney et al. (2015) for the periods 2041-2060, commonly referred to as period "2050". Two representative concentration pathways (RCP) were selected for each period (CCSM) to represent the moderate (RCP 4.5) and extreme climatic changes (RCP 8.5). RCP 8.5 assumes no climate policies will be undertaken either in the future or present, and it reflects very high emissions scenarios ( 1370-ppm $\mathrm{CO}_{2}$ equivalent by 2100; van Vuuren et al., 2011). Due to the future complexities and obtaining 
data for these periods, all the social variables remained constant, and were therefore used the current and future projections.

\subsection{Ecological modeling and validation}

Here, the maximum entropy algorithm applied in MaxEnt v. 3.4.3.e (Phillips et al., 2006) was used to appropriate the seven Ottelia species' distribution likelihood across our study area, subjecting it to constraints imposed by the environmental characteristics of the current data coordinates (16 variables, Table 1). We used the ENMeval package in R v. 3.6.2 (Muscarella et al., 2014) to perform a tuning experiment of our MaxEnt models. Using defaults for MaxEnt has resulted in poor-performing models (Radosavljevic and Anderson, 2014; Warren and Seifert, 2011). The 'block method', which divides data (presence points) into $\mathrm{k}$ = folds (Wenger and Olden, 2012), was employed to make the localities data into independent spatial test and training data sets. The regularization multipliers were set from 0.5 to 5 with increments of 0.5 in the $k$ of MaxEnt models. The feature combinations used were $L, H, L Q, L Q H, L Q H P$, and LQHPT; where $\mathrm{P}=$ product, $\mathrm{H}=$ hinge, $\mathrm{T}=$ threshold, $\mathrm{Q}=$ quadratic, and $\mathrm{L}=$ linear. The tuning experiment was applied for all the seven Ottelia species, then MaxEnt was run with the following parameters: 10 cross-validate replicates with 75\% training and 25\% test data, 10,000 background points, and 5,000 iterations. Validation of the models included performing the receiver operating characteristics (ROC) curve analysis to estimate the values of AUCtest and AUCtrain (Warren and Seifert, 2011). We also included the jackknife tests to analyze the relative importance of the selected variables. The models' results were given as averages of the ten replicates and converted into binary layers with 1 (presence) and 0 (absence) values for each species using the maximum training and sensitivity plus specificity (MTSS) as a threshold. MTSS is recommended as a conservative approach that minimizes commission and omission errors (Guisan et al., 2017; Liu et al., 2016). This analysis was performed in ArcGIS v. 10.5. Thus, for each species, one baseline (current) and two potential distribution layers were created based on the two scenarios and one GCM. Future habitat suitabilities were based on the current records and variables described before. For assessing the influence of climate on the distribution of Ottelia, we analyzed the distributional changes in habitat suitability for the seven species between the current and future thresholded models.

\subsection{Niche overlap assessment}

To assess the niche overlaps between Ottelia species, we used Schoener D (Schoener, 1968) and Hellinger I(Warren et al., 2008) statistics, implemented in ENM-tools v. 1.4.4 (Warren and Seifert, 2011). These two metrics compare niches overlaps of two species with values from 0 to 1 , with 1 signifying resemblance in the two niches and 0, no overlaps (Waren, 2010). We excluded 5\% of the occurrence data to account for probable errors in the data.

\section{Results}

\subsection{Ottelia distribution in Africa and model performance}


The correlation analysis indicated the following variables to be the best for predicting habitat suitability for the genus Ottelia: mean diurnal range (Bio2), mean temperature of the wettest quarter (Bio8), Isothermality (Bio3), mean temperature of the driest quarter (Bio9), precipitation of wettest month (Bio13) precipitation of driest month (Bio14), precipitation seasonality (Bio15), precipitation of warmest quarter (Bio18), and precipitation of coldest quarter (Bio19; Table S2). The AIC values of Ottelia species were considered to have the best effects when MaxEnt features were as follows: $O$. cylindrica, L, Q, H, P and $\mathrm{RM}=1.5 ; O$. exserta, $\mathrm{L}, \mathrm{Q}, \mathrm{H}, \mathrm{P}, \mathrm{T}$, and $\mathrm{RM}=1.5 ; O$. fischeri, $\mathrm{L}, \mathrm{Q}, \mathrm{H}, \mathrm{P}$, and $\mathrm{RM}=4 ; \mathrm{O}$. kunenensis, $\mathrm{L}, \mathrm{Q}, \mathrm{H}$, and $\mathrm{RM}=1.5 ;$ O. muricata, $\mathrm{L}, \mathrm{Q}, \mathrm{H}, \mathrm{P}, \mathrm{T}$, and $\mathrm{RM}=2.5 ; O$. ulvifolia, $\mathrm{L}, \mathrm{Q}, \mathrm{H}, \mathrm{P}, \mathrm{T}$, and $\mathrm{RM}=1$; and $O$. verdickii, $\mathrm{H}$ and $R M=0.5$. The MaxEnt AUC models were considered bad if the values were lower than 0.6 , good when the values ranged from 0.6 to 0.8 , and excellent with values from 0.8 to 0.987 the highest (Warren and Seifert, 2011). The current distribution of the seven species gave satisfactory AUC values as follows: $O$. cylindrica, $\mathrm{AUC}=0.973 ; O$. exserta, $\mathrm{AUC}=0.958 ; O$. fischeri, $\mathrm{AUC}=0.967 ; O$. kunenensis, $\mathrm{AUC}=0.980 ; O$. muricata, $\mathrm{AUC}=0.964 ; O$. ulvifolia, $\mathrm{AUC}=0.827$; and O. verdickii $\mathrm{AUC}=0.987$ (Table 2). Under the MaxEnt models, the genus Ottelia ENMs were, to a large extent, affected by the following set of three bioclimatic variables; Bio9 (mean temperature of the driest quarter), Bio12 (Annual precipitation), and Bio14 (Precipitation of the driest month), as well as elevation (Table 3). In the case of O. cylindica, O. ulvifolia, and $O$. verdickii, Bio12 highly contributed to their habitat suitability. Bio9 contributed highly to $O$. exserta, O. muricata, and $O$. ulvifolia models. Elevation mostly influenced the distribution of $O$. exserta, $O$. fischeri, O. kunenensis, and 0 . verdickii. O. cylindrica, 0 . kunenensis, and 0 . muricata distribution appeared to be limited by Bio14. The land use and Bio12 variables considerably influenced the distribution of $O$. cylindrica and $O$. fischeri, respectively, while the Water area variable highlighted its importance in affecting the distribution of 0 . exserta, $O$. fischeri.

\subsection{Predictions of potential distribution in the current and future climate change}

The current potential distribution indicated that $O$. ulvifolia occupied the greatest extent in Tropical Africa (Fig. 2). O. fischeri had the second-highest potential distribution, followed by 0 . muricata, 0 . exerta, 0 . cylindrica, 0 . kunenensis, and $O$. verdickii in that order. In Madagascar, where only O.ulvifolia occurs, revealed suitable high habitats for $O$. exserta and $O$. fischeri, with low suitability for $O$. cylindrica. Zambia, Angola, Botswana, south of DR Congo were revealed to be hotspots for the Ottelia species. New areas, including northern Sudan and Cameroon, revealed potential habitats for several Ottelia species with no previous records (Fig. 2, 3, S1). 
Table 1

Environmental covariates used in modeling the distribution Ottelia

\begin{tabular}{|c|c|c|c|c|}
\hline Category & Code & Variables & Unit & Source \\
\hline \multirow[t]{11}{*}{ Bioclimatic } & Bio2 & $\begin{array}{l}\text { Mean Diurnal Range (Mean of monthly } \\
\text { (max temp - min temp)) }\end{array}$ & ${ }^{\circ} \mathrm{C} * 10$ & WorldClim \\
\hline & Bio3 & Isothermality & - & WorldClim \\
\hline & Bio8 & Mean Temperature of Wettest Quarter & ${ }^{\circ} \mathrm{C} * 10$ & WorldClim \\
\hline & Bio9 & Mean Temperature of Driest Quarter & & \\
\hline & Bio12 & Annual precipitation & $\mathrm{mm} / \mathrm{month}$ & WorldClim \\
\hline & Bio13 & Precipitation of Wettest Month & $\mathrm{mm} / \mathrm{month}$ & WorldClim \\
\hline & Bio14 & Precipitation of Driest Month & $\mathrm{mm} / \mathrm{month}$ & WorldClim \\
\hline & Bio15 & $\begin{array}{l}\text { Precipitation Seasonality (Coefficient } \\
\text { of Variation }\end{array}$ & & WorldClim \\
\hline & Bio17 & Precipitation of Driest Quarter & $\mathrm{mm} /$ quarter & WorldClim \\
\hline & Bio18 & Precipitation of Warmest Quarter & $\mathrm{mm} /$ quarter & WorldClim \\
\hline & Bio19 & Precipitation of Coldest Quarter & $\mathrm{mm} /$ quarter & WorldClim \\
\hline \multirow[t]{2}{*}{ Topographic } & Elevation & Elevation & m. a.s.l. & STRM \\
\hline & Slope & Slope & $\%$ degree & $\begin{array}{l}\text { Derived from } \\
\text { elevation }\end{array}$ \\
\hline \multirow[t]{3}{*}{ Social } & Land use & - & - & FAO \\
\hline & $\begin{array}{l}\text { Population } \\
\text { density }\end{array}$ & - & People/km2 & SEDAC \\
\hline & Water area & - & $\begin{array}{l}\text { Water are } \\
\text { cover } / \mathrm{km} 2\end{array}$ & HydroSHEDS \\
\hline
\end{tabular}

Different Ottelia species observed and responded differently under future moderate and extreme greenhouse gas emissions for future potential distributions. Generally, there was an overall decrease in habitat suitability for all Ottelia by the 2050s under both RCP 4.5 and RCP 8.5 (Fig S2, Fig. 4). However, the latter observed a tremendous loss, as observed by reduction and increase in pixels, respectively (Table S3, Fig. 4). Moreover, under RCP 8.5, potentially suitable habitats in Madagascar and Angola for 0 . ulvifolia and 0 . exseta are lost (Fig. 4); however, they are minimally reduced in RCP 4.5 (Fig S2). Interestingly, $O$. verdickii showed the most gain in suitable areas under the extreme scenario RCP 8.5 compared to the other species (Fig. 4). We also observed a certain trend in both RCP scenarios where all species move towards the North Pole under, indicated by range expansion (Fig. 4, Fig S2) 
Table 2

Characteristics of the Ottelia species' spatial records used as predictors to model the tropical African freshwater SDMs, including model performance based on AUC values and standard deviation in parentheses

\begin{tabular}{|c|c|c|c|c|c|}
\hline \multirow[t]{2}{*}{ Species } & \multirow[t]{2}{*}{ Elevation } & \multirow{2}{*}{$\begin{array}{l}\text { No. of } \\
\text { presences }\end{array}$} & \multicolumn{3}{|c|}{ AUC (mean) } \\
\hline & & & Current & $\begin{array}{l}2050 \mathrm{~s} \text { (RCP } \\
8.5)\end{array}$ & $\begin{array}{l}2070(\mathrm{RCP} \\
8.5)\end{array}$ \\
\hline Ottelia cylindrica & $\begin{array}{l}1100- \\
1900\end{array}$ & 20 & $\begin{array}{l}0.988 \\
(0.021)\end{array}$ & $0.989(0.002)$ & $0.974(0.019)$ \\
\hline Ottelia exserta & $40-1200$ & 87 & $\begin{array}{l}0.974 \\
(0.019)\end{array}$ & $0.980(0.003)$ & $0.954(0.025)$ \\
\hline Ottelia fischeri & $\begin{array}{l}1200- \\
1600\end{array}$ & 12 & $\begin{array}{l}0.987 \\
(0.015)\end{array}$ & $0.962(0.021)$ & $0.878(0.102)$ \\
\hline $\begin{array}{l}\text { Ottelia } \\
\text { kunenensis }\end{array}$ & $\begin{array}{l}1030- \\
1200\end{array}$ & 22 & $\begin{array}{l}0.989 \\
(0.021)\end{array}$ & $0.970(0.033)$ & $0.969(0.035)$ \\
\hline Ottelia muricata & 1000 & 53 & $\begin{array}{l}0.969 \\
(0.019)\end{array}$ & $0.980(0.006)$ & $0.957(0.016)$ \\
\hline Ottelia ulvifolia & $183-1800$ & 274 & $\begin{array}{l}0.919 \\
(0.028)\end{array}$ & $0.926(0.006)$ & $0.831(0.034)$ \\
\hline Ottelia verdickii & $\begin{array}{l}1150- \\
1350\end{array}$ & 33 & $\begin{array}{l}0.987 \\
(0.015)\end{array}$ & $0.990(0.009)$ & $0.989(0.008)$ \\
\hline
\end{tabular}


Table 3

Mean relative contribution of each variable to the final model of the current distribution for each Ottelia species studied

\begin{tabular}{|llllllll|}
\hline Species & $\begin{array}{l}\text { Ottelia } \\
\text { cylindrica }\end{array}$ & $\begin{array}{l}\text { Ottelia } \\
\text { exserta }\end{array}$ & $\begin{array}{l}\text { Ottelia } \\
\text { fischeri }\end{array}$ & $\begin{array}{l}\text { Ottelia } \\
\text { kunenensis }\end{array}$ & $\begin{array}{l}\text { Ottelia } \\
\text { muricata }\end{array}$ & $\begin{array}{l}\text { Ottelia } \\
\text { ulvifolia }\end{array}$ & $\begin{array}{l}\text { Ottelia } \\
\text { verdickii }\end{array}$ \\
\hline Bio2 & 3.5 & 2.7 & 12.3 & 4.6 & 0.5 & 3.5 & 4.7 \\
\hline Bio3 & 0.3 & 2.9 & 0.9 & 6.2 & 2.9 & 4.8 & 0.5 \\
\hline Bio8 & 9.4 & 0.6 & 0.0 & 0.0 & 0.0 & 2.6 & 0.1 \\
\hline Bio9 & 2.5 & 23 & 0.7 & 3.6 & 24.9 & 10.3 & 0.0 \\
\hline Bio12 & 12.2 & 8.2 & 4.4 & 4.6 & 4.0 & 16 & 18.6 \\
\hline Bio13 & 2.3 & 0.7 & 0.1 & 0.2 & 0.2 & 21.9 & 0.0 \\
\hline Bio14 & 27.3 & 1.0 & 2 & 21.1 & 32.1 & 2.3 & 14.5 \\
\hline Bio15 & 0.7 & 2.5 & 0.1 & 0.0 & 0.6 & 1.5 & 0.4 \\
\hline Bio17 & 3.5 & 1.3 & 2.7 & 2.5 & 1.5 & 1.9 & 14.7 \\
\hline Bio18 & 3.0 & 9.8 & 1.5 & 9.7 & 10.5 & 4.7 & 6.1 \\
\hline Bio19 & 1.9 & 8.9 & 2.3 & 4.7 & 1.0 & 2.2 & 3.9 \\
\hline Elevation & 9.5 & 15.1 & 37.6 & 25.5 & 9.0 & 5.1 & 22.1 \\
\hline Slope & 1.3 & 6.0 & 8.9 & 10.9 & 3.1 & 3.6 & 5.1 \\
\hline Water area & 0.6 & 9.6 & 10.5 & 5.2 & 8.8 & 6.8 & 2.2 \\
\hline $\begin{array}{l}\text { Population } \\
\text { Density }\end{array}$ & 0.1 & 1.1 & 10.4 & 1.8 & 0.3 & 2.8 & 1.4 \\
\hline Land use & 22 & 6.7 & 5.3 & 1.7 & 0.8 & 10.2 & 5.7 \\
\hline 3.3. & & & & & & & \\
\hline
\end{tabular}

\subsection{Niche overlap analyses}

The overall niche overlap analysis indicated that Tropical African Ottelia species overlap considerably, according to $D$ statistics (Table 4). However, I statistics revealed an average overlap among all pairwise combinations (randomized values $<0.5$ ) (Table 4). O. fischeri observed the highest overlap with all the Ottelia species except for 0 . cylindrica, according to / value (randomized values $<0.5$, Table 4). There was almost complete overlap between $O$. kunenensis and $O$. muricata, and more or less none between $O$. kunenensis with $O$. verdickii ( $D=0.7011$ and 0.0963 , respectively; Table 4). 
Table 4

Niche overlap $D$ statistics (above diagonal) and / statistics (below diagonal)

\begin{tabular}{|c|c|c|c|c|c|c|c|}
\hline Species & $\begin{array}{l}\text { O. } \\
\text { cylindrica }\end{array}$ & $\begin{array}{l}\text { O. } \\
\text { exserta }\end{array}$ & $\begin{array}{l}\text { O. } \\
\text { kunenensis }\end{array}$ & $\begin{array}{l}\text { O. } \\
\text { muricata }\end{array}$ & $\begin{array}{l}\text { O. } \\
\text { ulvifolia }\end{array}$ & $\begin{array}{l}\text { O. } \\
\text { verdickii }\end{array}$ & $\begin{array}{l}\text { O. } \\
\text { fischeri }\end{array}$ \\
\hline $\begin{array}{l}\text { O. } \\
\text { cylindrica }\end{array}$ & 0.336 & 0.283 & 0.482 & 0.334 & 0.304 & 0.441 & \\
\hline O. exserta & 0.554 & 0 & 0.305 & 0.426 & 0.411 & 0.159 & 0.498 \\
\hline $\begin{array}{l}\text { O. } \\
\text { kunenensis }\end{array}$ & 0.537 & 0.532 & 0 & 0.701 & 0.290 & 0.096 & 0.312 \\
\hline O. muricata & 0.671 & 0.620 & 0.789 & 0 & 0.368 & 0.183 & 0.458 \\
\hline O. ulvifolia & 0.560 & 0.619 & 0.533 & 0.597 & 0 & 0.128 & 0.591 \\
\hline O. verdickii & 0.557 & 0.439 & 0.384 & 0.458 & 0.423 & 0 & 0.169 \\
\hline O. fischeri & 0.635 & 0.660 & 0.552 & 0.643 & 0.724 & 0.453 & 0 \\
\hline
\end{tabular}

\section{Discussion}

Mapping the habitat suitability in an ENM approach is advantageous because it offers critical notes on species management and conservation (Elith et al., 2011). Our current study highlighted the importance of assessing the ENMs of the Ottelia species for the current and future, using environmental covariates. All models for all species had AUC values above 0.831 , which was satisfactory and yielded insights into these species' future distribution with high accuracy levels (Table 2).

Predictions of MaxEnt Modeling for the seven Ottelia species' current distribution inferred that the present models predicted the habitat suitability of the Ottelia species distribution correctly (Fig. 2). Specifically, all species had higher suitabilities in southern Africa except $O$. ulvifolia, which was widely distributed in tropical Africa. Sighting higher suitable areas for the Ottelia species in northern and western Africa where no previous records were made was impressive, highlighting that these species might be present or persist in those regions. Nevertheless, our training tests of the models revealed that modeling using pseudo-presence models was not very precise. The likely explanation is that not all habitats within the range of occurrence are suitable for a species persistence (Verberk, 2011).

Environmental variables directly or indirectly affect SDMs (Austin, 2002). Direct variables, e.g., precipitation and temperature, may influence the survival of organisms and their physiology. On the other hand, elevation and water area (indirect variables) affect the abundance and geographical distribution of species; however, they do not significantly influence their physiology. Therefore, from our VIF correlation analyses and choice of variables in the present study, both the direct and indirect variables were observed to affect the distribution of Ottelia. 
The climatic variables making the highest contribution to the current habitat suitability and distribution of Ottelia differed between the species (Table 3). For 0 . cylindrica, a blend of Bio12 (annual precipitation), Bio14 (precipitation of the driest month), and land use variables explained its distributional range in the southern hemisphere. For 0 . ulvifolia, the combination of Bio9 (mean temperature of the driest quarter), Bio12 (annual precipitation), and Bio13 (precipitation of wettest month) inferred tolerance of a wide range of precipitation and temperature that illuminated its broad distributional range in Tropical Africa. Nevertheless, most species shared the variable related to elevation (O. exserta, $O$. fischeri, O. kunenensis, and $O$. verdickii), annual precipitation (Bio12) (O. cylyndrica, O. ulvifolia, and O. verdickii), and precipitation of the driest month (Bio14) (O. cylyndrica, O. kunenensis, and O. muricata). These factors and the others included in the current study are possibly linked to ecosystem competence and, in particular, the availability of nutrients (Zhang et al., 2020; Crossley et al., 2002). Climatic variations can aid evolutionary divergence (Petean et al., 2020; Rissler and Apodaca, 2007) by fostering species adaptation to new climatic environs (lannella et al., 2019). In addition, the cosmopolitan distribution of $O$. ulvifolia in Africa is supported by our simulations, which show that the species can persist in a broad range of environmental conditions.

Future projections showed that Ottelia's responses to climate change are highly variable (Fig. 3, Fig S1). Although certain species are expected to be largely untouched by climate change (e.g., O. veridkcii, in RCP 8.5, Fig. 3), others, especially in the RCP 8.5, are expected to lose a significant amount of appropriate habitat ranges (Fig. 4). The loss of appropriate ranges for a species means, at the very least, a rise in environmental pressure supporting mortality over the establishment in certain areas, which could result in local extinctions (Parmesan et al., 2015; Walck et al., 2011). The different responses to global climate change among closely related Ottelia species also indicate that macrophyte populations may disaggregate in the future, affecting the function and structure of the macrophyte assemblages they form (Alahuhta et al., 2020; García-Girón et al., 2020; Murphy et al., 2019).

Our observations from the niche overlap analyses show that most Ottelia species have similar but not equivalent climatic niches (Table 4). Despite a low to average overlap between the Ottelia species (Table 4), only $O$. exserta and $O$. fischeri shared two identical environmental variables (elevation and water area) that contributed significantly to their distribution (Table 3). While all these species were revealed to have different ecological requirements, their habitat suitability was mostly temperature and precipitation-dependent (Table 3). The low to average niche overlap between the Ottelia species may imply that they are distinguished from one another by a variety of abiotic factors. While in the current study, we evaluated the niche overlaps of the seven Ottelia species based on bioclimatic characteristics, complex and competitive interactions, on the other hand, which may shape macrophyte assemblages (Murphy et al., 2019; Kennedy et al., 2015).

The present study did not include the effects of $\mathrm{pH}$ and nutrient availability of water bodies where species occur and their influence on aquatic species. Therefore, future studies should assess the effects of $\mathrm{pH}$ and nutrient availability on the distribution of aquatic macrophytes. Regardless, the observed areas of high habitat suitability for the Ottelia species could be observed as potential future refuges. In order to 
anticipate the intricate impacts that climate change will have on community assemblages, it is crucial to locate the areas that will most likely persist under adverse future climate change (Pennino et al., 2020; Monsarrat et al., 2019).

Usually, when performing ENMs, the occurrence data should be independent of each other and obtained in an unbiased and random manner (Graham et al., 2004). However, given the inaccessibility of certain African countries/regions, collecting data to meet these criteria is often difficult, and direct sampling of aquatic macrophytes found in deep forests (e.g., Congo) or politically unstable areas could be impossible (Murphy et al., 2019). Furthermore, other water bodies may be home to hippos and crocodiles, making occurrence records for aquatic macrophytes challenging to obtain (Kennedy et al., 2015). Finally, complex river channels can be challenging to traverse. Given this, sampling the whole African continent might not be optimal for the reasons mentioned. The presence records used in the present study were obtained from credible sources viz. GBIF, museum herbariums, and published literature. The possibility of selection bias was low in this case was therefore independent. Nonetheless, due to the limitations of the sampling efforts in Africa, this data remains somewhat biased. Even so, the modeling analyses used 10,000 background points (absence data) that were generated randomly by MaxEnt. Background points increase the chances of producing the best fitting probability distribution for estimating habitat suitability (Elth et al., 2011). Also, the modeling approach's environmental covariates were cautiously selected to reduce omission and commission errors. Integration of many predictive covariates in ENM generates overfitting, constraining the spatial range of predictions (Beaumount et al., 2005). Therefore, an optimum number of predictors must be calculated to maximize the effectiveness of the analysis. Regardless of the challenges, we modeled the distribution of seven Ottelia species using Maxent and presence-only data and produced reliable models similar to Guo et al. (2019), as well as other aquatic macrophytes (Heneidy et al., 2019; McGarvey et al., 2018).

The current study assessed the probable effects of future climate change on the distribution of seven Ottelia species in African freshwater basins. Studies such as this, which use predictive models based on recorded data, established biological parameters, and best possible climate simulations representing the full spectrum of outcomes, offer policymakers and experts critical knowledge to set goals for mitigation and conservation in the future. The present findings highlighted that among the most vital variables influencing the distribution of Ottelia were elevation, annual precipitation (Bio12), and precipitation of the driest month (Bio14). Future projections of the habitat suitability showed that the currently suitable area of the Ottelia species would decline by 2050s under both climate scenarios RCP4.5 and RCP 8.5, with the pessimistic scenario having a tremendous loss. Extensive reductions in suitable areas under the future climate scenarios indicate the probability of the species being threatened or endangered if the Otellia habitats' keen management and conservation are not observed. While the characteristics of the Ottelia species' distribution are pretty satisfactory from this study, more surveys are encouraged throughout tropical Africa to assess the Ottelia species distribution.

Generally, we have demonstrated that global climate change would constitute a severe threat to Ottelia species, even though the current distribution ranges of most species are closely bound to the water 
bodies of the greater central-southern African region, where the local communities are highly dependent on natural water bodies for water. This situation renders many species in decline situations, covering areas where conservation management and scientific research are yet to be undertaken and becoming increasingly vulnerable to various threats. While the current study concentrated on genus Ottelia, and particularly the African species, we acknowledge that many aquatic macrophytes need similar careful consideration. As a result, although we recommend more proactive attempts to safeguard Ottelia from increasing threats, we also recommend that initiatives be made to evaluate and utilize accessible data continuously (e.g., checklists), together with countrywide level assessments (e.g., Kennedy et al., 2015), to enhance conservation protection of aquatic macrophytes in Africa. Such discussions are currently underway in the African region and are imperative to building preparedness capacity for the ongoing effects of climate change on African waterbodies. Therefore, results from this study are especially pertinent to elaborate the conservation schemes for aquatic macrophytes. Lastly, our findings call for further research into the genus Ottelia from a variety of viewpoints, including not only the ENMs and ecological aspects but also the genus' taxonomy, physiology, and molecular barcoding.

\section{Declarations}

\section{Conflicts of Interest}

The authors declare no competing conflict of interests

\section{Acknowledgments}

We are grateful to John M. Ndung'u for early consultations on this study's statistical approach. In addition, we would like to thank Drs. Valerie F. Masocha (Xishuangbanna Institute of Tropical Botanical Garden) and Yeshitila Mekbib (Ethiopian Biodiversity Institute) for thought-provoking discussions regarding the study. Thanks are also due to the Kasanka trust for providing logistics during our fieldwork in Zambia. We acknowledge the Department of National Parks and Wildlife, Zambia, for the competent authorities of permits during our fieldwork in Zambia. This research was funded by the Strategic Priority Research Program of the Chinese Academy of Sciences (No. XDB 31000000), the National Natural Science Foundation of China (No. 32070253), and the Sino-Africa Joint Research Center (No. SAJC201322).

\section{References}

Aiello-Lammens, M.E., Boria, R.A., Radosavljevic, A., et al., 2015. spThin: An R package for spatial thinning of species occurrence records for use in ecological niche models. Ecography, 38(5), 541-545.

Alahuhta, J., Antikainen, H., Hjort, J., et al., 2020. Current climate overrides historical effects on species richness and range size of freshwater plants in Europe and North America. J. Ecol. 108(4), 1262-1275. 
Archer, E., Dziba, L., Mulongoy, K.J., et al., 2018. The regional assessment report on biodiversity and ecosystem services for Africa: summary for policymakers.

Austin, M.P. 2002. Spatial prediction of species distribution: an interface between ecological theory and statistical modelling. Ecol. Modell. 157(2-3), 101-118.

Bailie E.M., Hihon-Taylor C., Stuart SN, eds, 2004 .2004 IUCN Red List of Threatened Species: A Global Species Assessment. Cambridge (United Kingdom): IUCN.

Beaumont, L.J., Hughes, L., Poulsen, M. 2005. Predicting species distributions: use of climatic parameters in BIOCLIM and its impact on predictions of species' current and future distributions. Ecol. Modell. 186(2), 251-270.

Bernstein, L., Bosch, P., Canziani, O., et al., 2008. IPCC, 2007: climate change 2007: synthesis report.

Butchart, S. H., Walpole, M., Collen, B., et al., 2010. Global biodiversity: indicators of recent declines. Science, 328(5982), 1164-1168.

Cavé, L., Beekman, H. E., Weaver, J., 2003. Impact of Climate Change on Groundwater Recharge Estimation. Groundwater recharge estimation in southern Africa, 189.

Center for International Earth Science Information Network - CIESIN - Columbia University. Gridded Population of the World, Version 4 (GPWv4): Population Density, Revision 10. Palisades, NY: NASA Socioeconomic Data and Applications Center (SEDAC) 2017. doi:10.7927/H4DZ068D

Chen, J.M., Du, Z.Y., Long, Z.C., et al., 2017. Molecular divergence among varieties of Ottelia acuminata (Hydrocharitaceae) in the Yunnan-Guizhou Plateau. Aquat. Bot. 140, 62-68.

Chesson, P. 2000. Mechanisms of maintenance of species diversity. Ann. Rev. Ecol. Syst. 31(1), 343-366.

Corlett, R.T. 2016. Plant diversity in a changing world: status, trends, and conservation needs. Plant Divers. 38(1), 10-16.

Cook C.D., Urmi-König K., 1984. A revision of the genus Ottelia (Hydrocharitaceae). 2. The species of Eurasia, Australasia and America. Aquat. Bot. 20, 131-177.

Cook, C.D., Symoens, J.J., Urmi-König, K., 1983. A revision of the genus Ottelia (hydrocharicaea) I. Generic considerations. Aquat. Bot. 18, 263-274.

Crossley, M.N., Dennison, W.C., Williams, R.R., et al., 2002. The interaction of water flow and nutrients on aquatic plant growth. Hydrobiologia, 489(1), 63-70.

De Dominicis, F., Pallini, C., Annalisa, S., 2015. Rivers, Dams and Large-scale Hydraulic Works in Postcolonial Africa. 
De Wit, M., Stankiewicz, J., 2006. Changes in surface water supply across Africa with predicted climate change. Science, 311(5769), 1917-1921.

Dormann, C.F., McPherson, J., Araújo, M., et al., 2007. Methods to account for spatial autocorrelation in the analysis of species distributional data: a review. Ecography, 30(5): 609-628.

Elith, J., Graham, C.,P. Anderson, R., et al., 2006. Novel methods improve prediction of species' distributions from occurrence data. Ecography, 29(2), 129-151.

Elith, J., Leathwick, J.R., 2009. "Species distribution models: ecological explanation and prediction across space and time." Ann. Rev. Ecol. Evol. Syst. 40, 677-697.

Elith, J., Phillips, S.J., Hastie, T., et al., 2011. A statistical explanation of MaxEnt for ecologists. Diversity Distrib. 17(1), 43-57.

Fan, X.R., Njeri, H.K., Li, W., et al., 2019. Abundant historical gene flow within and among river systems for populations of Ottelia acuminata var. jingxiensis, an endangered macrophyte from southwest China. Aquat. Bot. 157, 1-9.

Ferrer-Gallego, P.P., Boisset, F., Simpson, D.A., 2016. Typification of the African endemic plant Ottelia exserta (Hydrocharitaceae). Kew Bull. 71(2), 32.

Graham, C.H., Ferrier, S., Huettman, F., et al., 2004. New developments in museum-based informatics and applications in biodiversity analysis. Trends Ecol. Evol. 19, 497-503.

García-Girón, J., Heino, J., Baastrup-Spohr, L., et al., 2020. Global patterns and determinants of lake macrophyte taxonomic, functional and phylogenetic beta diversity. Sci. Total Environ. 723, 138021.

Gent, P.R., Danabasoglu, G., Donner, L.J., et al., 2011. The community climate system model version 4. J. Clim. 24(19), 4973-4991.

Guisan, A., Thuiller, W., Zimmermann, N.E., 2017. Habitat Suitability and Distribution Models: With Applications in R; Cambridge University Press: Cambridge, UK. ISBN 0521765137.

Guo, J.L., Yu, Y.H., Zhang, J.W., et al., 2019. Conservation strategy for aquatic plants: endangered Ottelia acuminata (Hydrocharitaceae) as a case study. Biodivers. Conserv. 28(6), 1533-1548.

Hanski, I., Zurita, G.A., Bellocq, M.I., et al., 2013. Species-fragmented area relationship. PNAS. 110(31), 12715-12720.

Heikkinen, R. K., Luoto, M., Araújo, M. B., et al., 2006. Methods and uncertainties in bioclimatic envelope modeling under climate change. Prog. Phys. Geog. 30(6), 751-777.

Heneidy, S.Z., Halmy, M.W.A., Fakhry, A.M., et al., 2019. The status and potential distribution of Hydrocotyle umbellata L. and Salvinia auriculata Aubl. under climate change scenarios. Aquat. 
Ecol. 53(4), 509-528.

Hijmans, R.J., Cameron, S.E., Parra, J.L., 2005. Very high resolution interpolated climate surfaces for global land areas. Int. J. Climatol. 25, 1965-1978.

Hirzel, A.H., Le Lay, G., Helfer, V., et al., 2006. Evaluating the ability of habitat suitability models to predict species presences. Ecol. Model. 199(2), 142-152.

Hoekstra, J.M., Boucher, T.M., Ricketts, T.H., et al., 2005. Confronting a biome crisis: global disparities of habitat loss and protection. Ecol. Lett. 8(1), 23-29.

lannella, M., D'Alessandro, P., Longo, S., et al., 2019. New records and potential distribution by Ecological Niche Modeling of Monoxia obesula in the Mediterranean area. Bull. Insectology. 71(1), 135-142.

Intergovernmental Panel on Climate Change. Part B: Regional Aspects. Contribution of Working Group II to the Fifth Assessment Report of the Intergovernmental Panel on Climate Change. In Climate Change 2014: Impacts, Adaptation, and Vulnerability; Barros, V.R., Field, C.B., Dokken, D.J., Mastrandrea, M.D., Mach, K.J., Bilir, T.E., Chatterjee, M., Ebi, K.L., Estrada, Y.O., Genova, R.C., Eds.; Cambridge University Press: Cambridge, UK; New York, NY, USA, 2014; 1-669.

Ito, Y., Tanaka, N., Barfod, A. S., et al., 2019. Molecular phylogenetic species delimitation in the aquatic genus Ottelia (Hydrocharitaceae) reveals cryptic diversity within a widespread species. J. Plant. Res. 132(3), 335-344.

Kennedy, M.P., Lang, P., Grimaldo, J.T., et al., 2015. Environmental drivers of aquatic macrophyte communities in southern tropical African rivers: Zambia as a case study. Aquat. Bot. 124, 19-28.

Lewis, L.A., Berry, L., 2012. African environments and resources. Routled

Li, Z.Z., Lu, M.X., Gichira, A.W., et al., 2019. Genetic diversity and population structure of Ottelia acuminata var. jingxiensis, an endangered endemic aquatic plant from southwest China. Aquat. Bot. 152, 20-26.

Li, Z., Ngarega, B.K., Lehtonen, S., et al., 2020. Cryptic diversity within the African aquatic plant Ottelia ulvifolia (Hydrocharitaceae) revealed by population genetic and phylogenetic analyses. J. Plant Res. 133, 372-381.

Liu, C., Newell, G., White, M., 2016. On the selection of thresholds for predicting species occurrence with presence-only data. Ecol. Evol. 6, 337-348.

McGarvey, D.J., Menon, M., Woods, T., et al., 2018. On the use of climate covariates in aquatic species distribution models: are we at risk of throwing out the baby with the bathwater?. Ecography, 41(4), 695712. 
McLaughlin, B.C., Ackerly, D.D., Klos, P.Z., et al., 2017. Hydrologic refugia, plants, and climate change. Glob. Change Biol. 23(8), 2941-2961.

McSweeney, C.F., Jones, R.G., Lee, R.W., et al., 2015. Selecting CMIP5 GCMs for downscaling over multiple regions. Clim. Dyn. 44(11), 3237-3260.

Meinshausen, M., Smith, S.J., Calvin, K., et al., 2011. The RCP greenhouse gas concentrations and their extensions from 1765 to 2300 . Clim. Change 109, 213-241.

Misra, A.K. 2014. Climate change and challenges of water and food security. Int. J. Sustain. Built Environ. 3(1), 153-165.

Monsarrat, S., Jarvie, S., Svenning, J.C., 2019. Anthropocene refugia: integrating history and predictive modelling to assess the space available for biodiversity in a human-dominated world. Philosophical Transactions of the Royal Society B, 374(1788), 20190219.

Muscarella, R., Galante, P.J., Soley-Guardia, M., et al., 2014. ENM eval: An R package for conducting spatially independent evaluations and estimating optimal model complexity for Maxent ecological niche models. Methods Ecol. Evol. 5(11), 1198-1205.

Murphy, K., Efremov, A., Davidson, T.A., et al., 2019. World distribution, diversity and endemism of aquatic macrophytes. Aquat. Bot. 158, 103127.

Nori, J., Rojas-Soto, 0., 2019. On the environmental background of aquatic organisms for ecological niche modeling: a call for caution. Aquat. Ecol. 53, 595-605.

Nyong, A., and Niang-Diop, I., 2006. Impacts of climate change in the tropics: the African experience. Avoiding dangerous climate change, 237.

Parmesan, C., and Hanley, M.E., 2015. Plants and climate change: complexities and surprises. Ann. Bot. 116(6), 849-864.

Pennino, M.G., Coll, M., Albo-Puigserver, M.,et al., 2020. Current and future influence of environmental factors on small pelagic fish distributions in the Northwestern Mediterranean Sea. Front. Mar. Sci. 7, 622.

Plant List 2010. The plant list. Available at: https://www.theplantlist.org

Phillips, S.J., and Dudík, M., 2008. Modeling of species distributions with Maxent: new extensions and a comprehensive evaluation. Ecography, 31(2), 161-175.

Phillips, S.J., Anderson, R.P., Schapire, RE, 2006. Maximum entropy modeling of species geographic distributions. Ecol. Modell. 190(3-4), 231-259.

Petean, F.F., Naylor, G.J., and Lima, S.M., 2020. Integrative taxonomy identifies a new stingray species of the genus Hypanus Rafinesque, 1818 (Dasyatidae, Myliobatiformes), from the Tropical Southwestern 
Atlantic. J. Fish Biol. 97(4), 1120-1142.

Pressey, R.L., Cabeza, M., Watts, M.E., et al., 2007. Conservation planning in a changing world. Trends Ecol. Evol. 22(11), 583-592.

Rissler, L.J., Apodaca, J.J., 2007. Adding more ecology into species delimitation: ecological niche models and phylogeography help define cryptic species in the black salamander (Aneides flavipunctatus). Syst. Biol. 56(6), 924-942.

Radosavljevic, A., and Anderson, R.P., 2014 Making better Maxent models of species distributions: complexity, overfitting and evaluation. J .Biogeogr. 41:629-643

R-Core-Team, 2019. R: A language and environment for statistical computing. Vienna, Austria: R Foundation for Statistical Computing.

Serdeczny, O., Adams, S., Baarsch, F., et al., 2017. Climate change impacts in Sub-Saharan Africa: from physical changes to their social repercussions. Reg. Environ. Change, 17(6), 1585-1600.

Shepard, D., 2019. Global warming: Severe consequences for Africa: New report projects greater temperature increases. Africa Renewal, 32(3), 34-34.

Symoens J.J., 2009. Hydrocharitaceae. Flora Zambesiaca 12:31-32

Thornton, P.K., Jones, P.G., Ericksen, P.J., et al., 2011. Agriculture and food systems in sub-Saharan Africa in a 4 C+ world. Philos. Trans. A. Math. Phys. Eng. Sci. 369(1934), 117-136.

van Proosdij, A.S., Sosef, M.S., Wieringa, J.J., et al., 2016. Minimum required number of specimen records to develop accurate species distribution models. Ecography, 39(6), 542-552.

Van Vuuren, D.P., Edmonds, J., Kainuma, M., et al., 2011. The representative concentration pathways: an overview. Clim. Change, 109(1-2), 5.

Verberk, WCEP, 2011. Explaining general patterns in species abundance and distributions. Nat. Edu. Knowl. 3(10), 38.

Walck, J. L., Hidayati, S. N., Dixon, K. W., et al., 2011. Climate change and plant regeneration from seed. Glob. Change Biol. 17(6), 2145-2161.

Warren, D.L., Glor, R.E., and Turelli, M., 2008. Environmental niche equivalency versus conservatism: quantitative approaches to niche evolution. Evolution, 62(11), 2868-2883.

Warren, D.L., and Seifert, S.N., 2011. Ecological niche modeling in Maxent: The importance of model complexity and the performance of model selection criteria. Ecol. Appl. 21, 335-342. 
Wenger, S.J., and Olden J.D., 2012. Assessing transferability of ecological models: an underappreciated aspect of statistical validation. Methods. Ecol. Evol. 3:260-267

Wilson, K.A., McBride, M.F., Bode, M., et al., 2006. Prioritizing global conservation efforts. Nature, 440(7082), 337-340.

Zhang, P., Kuramae, A., Van Leeuwen, C.H., et al., 2020. Interactive effects of rising temperature and nutrient enrichment on aquatic plant growth, stoichiometry, and palatability. Front. Plant Sci. 11, 58.

Zhai, S.H., Yin, G.S., Yang, X.H. 2018. Population genetics of the endangered and wild edible plant Ottelia acuminata in southwestern China using novel SSR markers. Biochem. Genet. 56(3), 235-254.

\section{Figures}
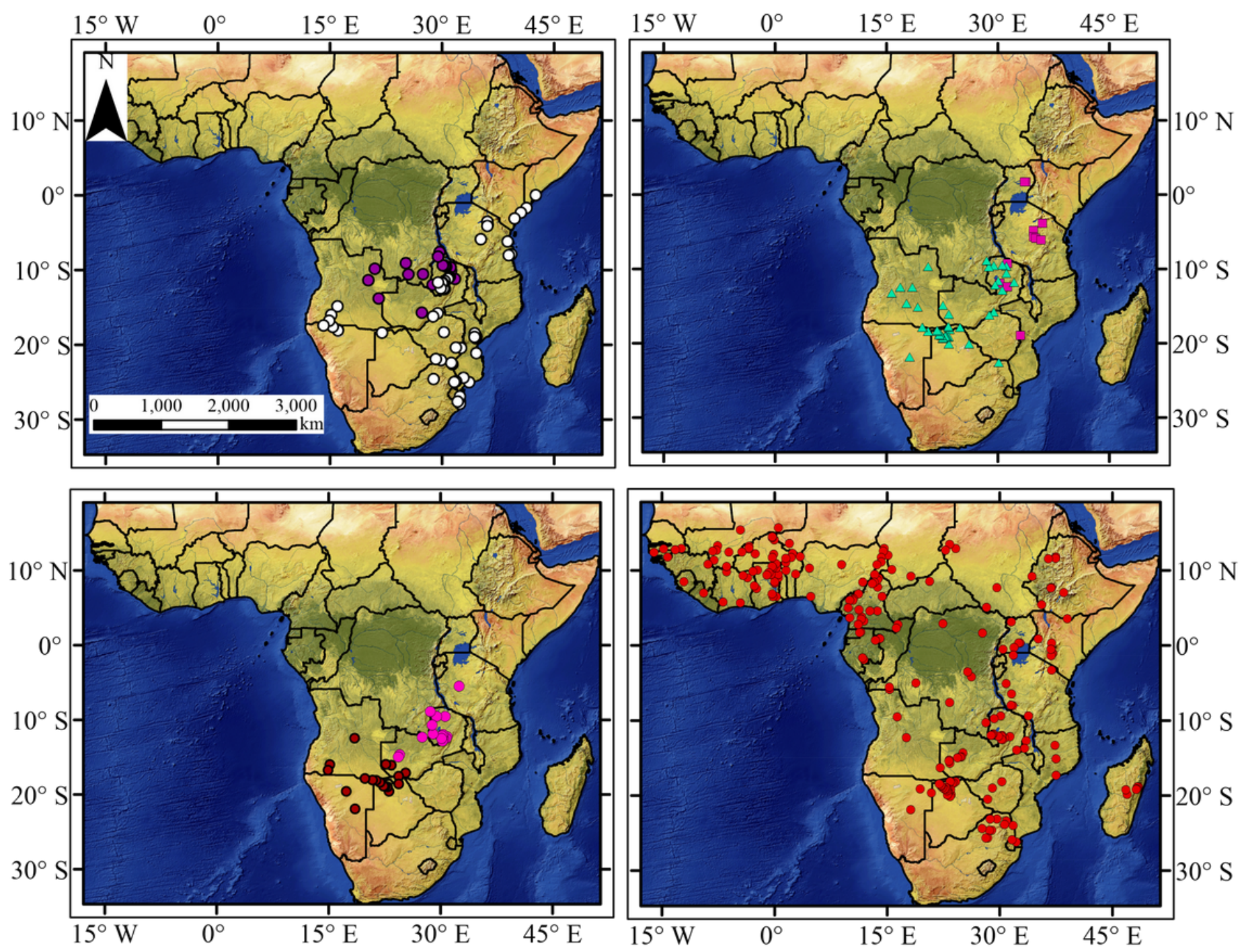
- O. cylindrica
- O. kunenensis
- O. exserta
- O. fischeri

- O. muricata

- O. verdickii

- O. ulvifolia 
Figure 1

Map of the occurrences of Ottelia spp. Occurrences of Ottelia cylindrica $(n=20), 0$. exserta $(n=87), 0$. fischeri $(n=12), 0$. kunenensis $(n=22), 0$. muricata $(n=53), 0$. ulvifolia $(n=274), 0$. verdickii $(n=33)$ used for modeling

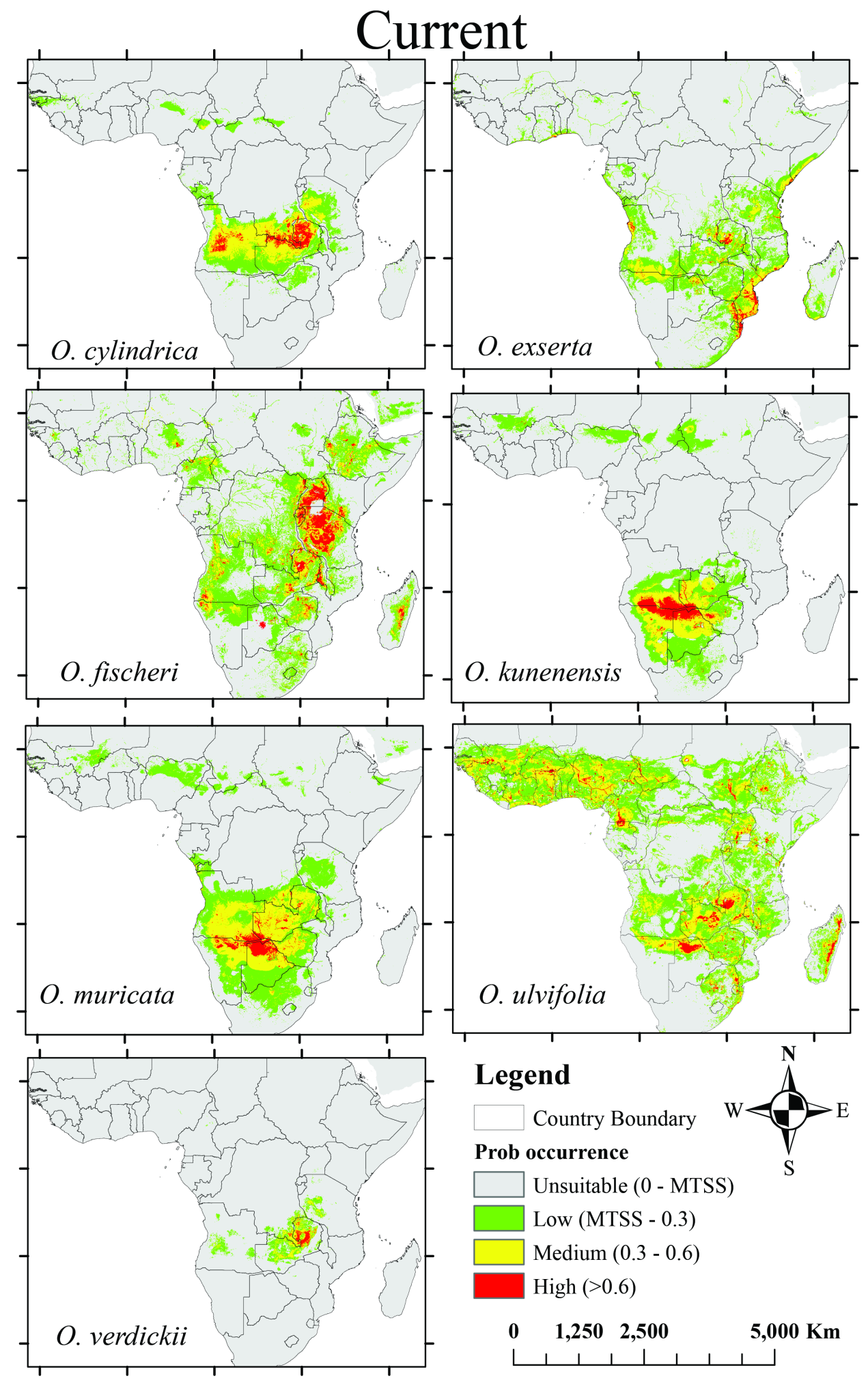

Figure 2 
Current potential distribution of Ottelia species in Africa. Potential distributions were based on different environmental variables

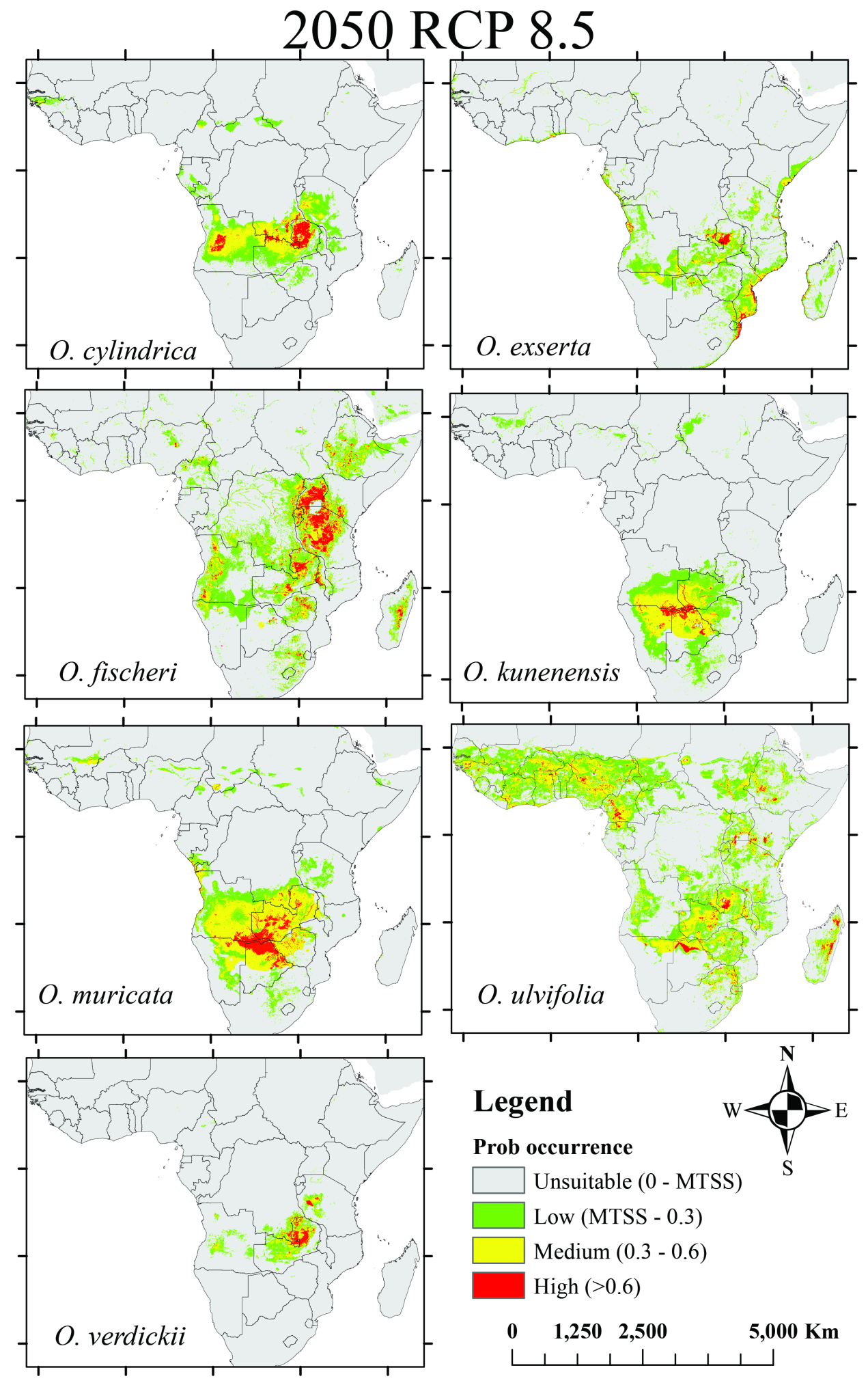

Figure 3

Predicted potential distribution of the Ottelia species in the 2050s for the RCP 8.5 using the Maxent models 


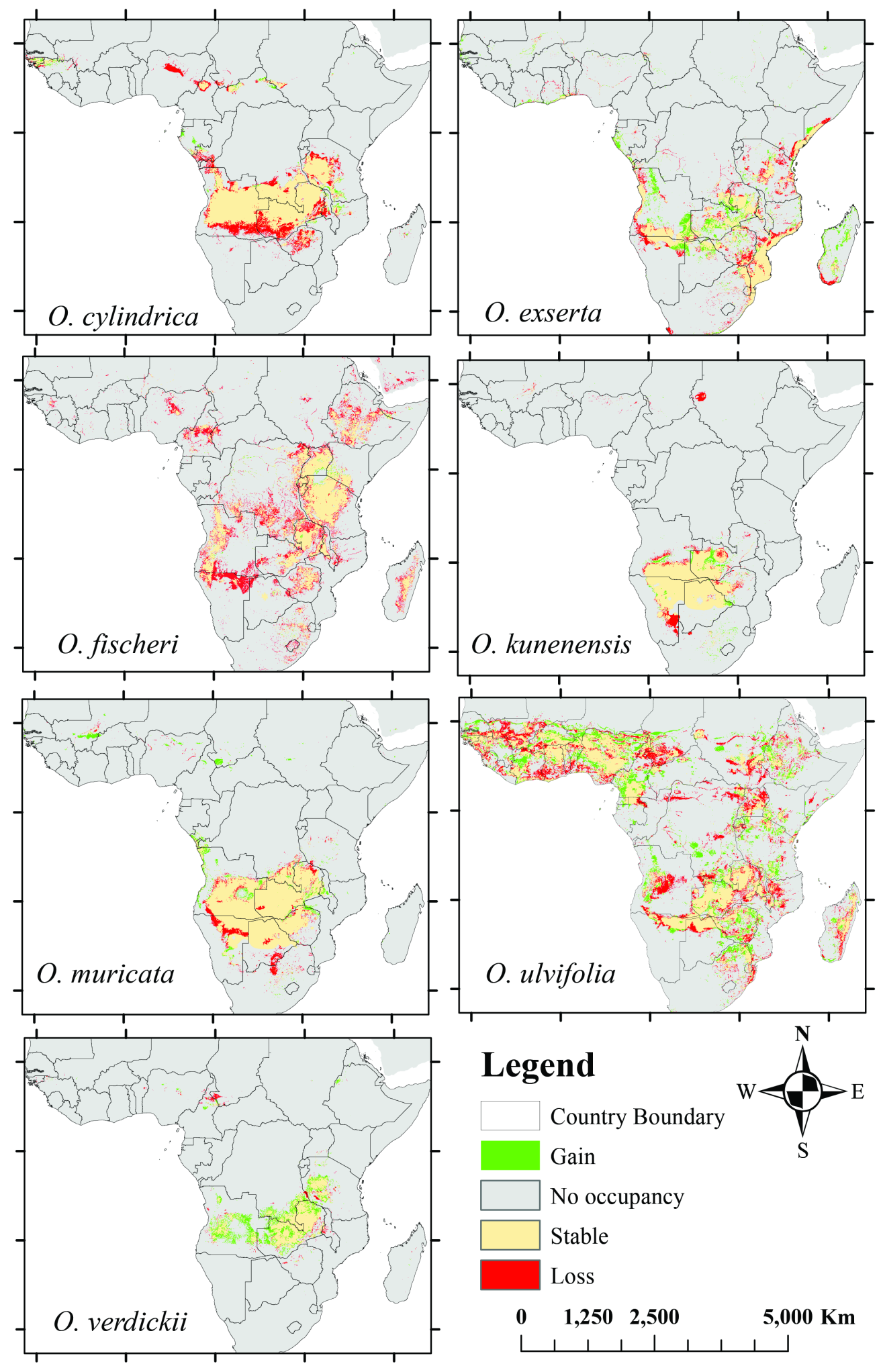

\section{Figure 4}

Predicted change in the distribution of Otelia species under RCP 8.5 scenario for the year 2050s

\section{Supplementary Files}

This is a list of supplementary files associated with this preprint. Click to download. 
- FigS1.pdf

- Figs2.pdf

- Tables2.docx

- TableS3.docx 